\title{
PHOTOCHEMICAL DECOMPOSITION OF ORGANIC PHOSPHORUS COMPOUND INCLUDING POLYPHOSPHATES BY ULTRA-VIOLET RADIATION AND ACID-HYDROLYSIS
}

Jun-ichi ITOH and Masashi KOMATA

Kitami Institute of Technology, Koen-cho 165, Kitami-shi, Hokkaido, 090 Japan

\begin{abstract}
Total phosphorus in the samples containing organic phosphorus compound, organic polyphosphate and inorganic polyphosphate were determined as orthophosphates by ionchromatography after acid-hydrolysis and photochemical decomposition. With the procedure, oxalic acid was used for thermal acid-hydrolysis of polyphosphate chain, and ultra-violet radiation for photo-oxidation of organic parts of compound and oxalic acid. The method avoids contamination of the final phosphate solution with excess acids those are used in conventional acid-hydrolysis methods.
\end{abstract}

\section{INTRODUCTION}

We often encounter the necessities to convert various phosphorus compounds to orthophosphate. For example, total phosphorus concentration of natural or waste water is determined as orthophosphate by a molybdenum Received November 15, 1993; Accepted December 20, 1993 
blue photometry ${ }^{1}$ or by an ion-chromatography ${ }^{2}$. Naturally occurring phosphorus compounds are mostly in the form of inorganic and organic phosphates $^{3}$, and compounds in waste water may also contain P-C, P-S and/or P-halogen bond. For such samples, it has been pointed out that the conventional thermal acid-hydrolysis using sulfuric acid, nitric acid and/or persulfate are incomplete, and the combined use of photo-oxidation and the acid-hydrolysis was recommended ${ }^{3-7}$.

We have reported a combined method of the photochemical decomposition and an ion-chromatography for organic sulfur, organic halogen ${ }^{8}$ and organic phosphorus compounds ${ }^{2}$. This is convenient for the determination of those elements as sulfate, halide and phosphate ions by the ion-chromatography, because the method does not use a large amounts of acid which interfere with the ion-chromatography. In the study, we found that only inorganic and organic polyphosphates did not liberate orthophosphate. In this report, a new thermal acid-hydrolysis method for polyphosphates using oxalic acid as an alternative to mineral acids is recommended. After the hydrolysis reaction, organic phosphorus compounds and oxalic acid are photochemically decomposed to orthophosphate and carbon dioxide.

\section{EXPERIMENTAL}

\section{$\underline{\text { Reagent and apparatus }}$}

A standard phosphates solution was prepared by dissolving potassium dihydrogen phosphate in deionized water and used for calibration. Monopotassium adenosine 5'-diphosphate (ADP), disodium adenosine 5'triphosphate (ATP), sodium diphosphate and sodium metaphosphate were dissolved in deionized water. The concentration of solutions as orthophosphate were determined by molybdenum blue spectrophotometry following the decomposition using sulfuric and nitric acid ${ }^{1}$.

The photochemical reactions were carried out in a type of apparatus 
described previously ${ }^{8}$. The light source is a $1 \mathrm{kw}$ high-pressure mercury-arc lamp (Toshiba Denzai type H1000PQ/4). An ion-chromatograph system consists of a pump (Tosoh HLC-803D), a conductometric detector (Tosoh CM8) and a separating column (TSKgel IC- Anion PW, $4.6 \mathrm{~mm}$ i.d. x 50mm). A gluconate-borax buffer system was used for eluent.

\section{Procedure}

A sample solution $\left(5 \mathrm{~cm}^{3}\right)$ was pipetted into a fused-silica tube, and $0.5 \mathrm{~cm}^{3}$ of $1 \mathrm{~mol} / \mathrm{dm}^{3}$ oxalic acid was added to the solution. After heating for $2 \mathrm{hr}$ in water bath, the tube was placed around the UV lamp and $0.5 \mathrm{~cm}^{3}$ of $3 \%$ hydrogen peroxide solution was added to the solution. After irradiation for $30 \mathrm{~min}$, the concentration of orthophosphate was determined by the ionchromatography.

\section{RESULTS AND DISCUSSION}

\section{Photochemical decomposition}

Recoveries of orthophosphate after the photochemical decomposition of sodium diphosphate, sodium metaphosphate, monopotassium adenosine 5'diphosphate and disodium adenosine 5'-triphosphate were examined according to the procedure described above except that the acid-hydrolysis was omitted. Results were listed in TABLE 1 with those of the decomposition of phosphorus compounds containing no polyphosphate-groups. Poor recoveries were obtained for organic and inorganic polyphosphates, whereas phosphorus compounds containing no polyphosphate-groups were decomposed almost quantitatively. On the other hand, it has been pointed out that the acid-digestion method was incomplete for organic phosphorus compounds ${ }^{3}$. Then it can be concluded that the photochemical decomposition and the acid hydrolysis work complementarily for phosphorus compounds as shown below. 


\section{Cl-P, S-P, R-P, R-O-P-O-P-O-P-O $\cdots$

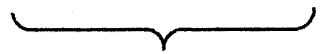 \\ UV-irradiation

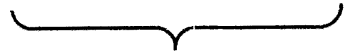 \\ acid-hydrolysis}

\section{Catalytic effect of platinum}

It was found that the photochemical hydrolysis reaction of diphosphate was accelerated when a platinum mesh sheet was placed in the reaction tube. The recoveries of orthophosphate after $30 \mathrm{~min}$ irradiation were $42 \%$ and $4.5 \%$, with and without the platinum mesh respectively. Catalytic effects were also observed for $\mathrm{Al}, \mathrm{Cu}, \mathrm{Sn}$, and $\mathrm{Zn}$, but those effects were small. The catalytic activity of platinum, however, stopped after $60 \mathrm{~min}$, the maximum recovery of orthophosphate was $75 \%$.

\section{Acid-hydrolysis using oxalic acid}

As mentioned above, the thermal acid-hydrolysis using strong mineral acid converts polyphosphate to orthophosphate quantitatively. To avoid a large quantities of acid contamination of phosphate samples, the hydrolysis using oxalic acid was examined. Oxalic acid is an appreciably strong acid and can be oxidized to carbon dioxide and water by UV-irradiation.

FIGURE 1 shows the results of the thermal acid hydrolysis of adenosine 5'-triphosphate at various $\mathrm{pH}$ conditions followed by UV-irradiation for 30 min. A $100 \%$ conversion was achieved by heating for $90 \mathrm{~min}$ at $\mathrm{pH} 1.45$ and by UV-irradiation for $30 \mathrm{~min}$. The results of the decomposition of other polyphosphates are shown in FIGURE 2 and TABLE 1. All phosphates tested were quantitatively hydrolyzed to orthophosphate by heating for $90 \mathrm{~min}$ at $\mathrm{pH} 1.5$ and UV-irradiation for $30 \mathrm{~min}$. There were no peaks in the chromatogram of IC analysis of the irradiated solution other than those of nitrate and carbonate. 
TABLE 1 Decomposition of organic and inorganic phosphorous compounds

\begin{tabular}{|c|c|c|c|c|c|}
\hline Sample & $\begin{array}{l}\text { UV-Irradi- } \\
\text { ation(min) }\end{array}$ & $\begin{array}{l}\text { Acid-hydro- } \\
\text { lysis }^{b}(\mathrm{~min})\end{array}$ & $\begin{array}{l}\text { Calcuated } \\
\text { (ppm as P) }\end{array}$ & $\begin{array}{l}\text { Observed } \\
\text { (ppm as P) }\end{array}$ & $\begin{array}{r}\text { Recovery } \\
(\%)\end{array}$ \\
\hline $\begin{array}{l}\text { Potassium } \\
\text { phosphonate }^{\text {a) }}\end{array}$ & 30 & $-c)$ & 3.85 & 3.85 & 100.0 \\
\hline $\begin{array}{l}\text { Triethyl } \\
\text { phosphite }^{\text {a) }}\end{array}$ & 30 & - & 4.06 & 4.07 & 100.2 \\
\hline $\begin{array}{l}\text { Triethyl } \\
\text { phosphate }^{\text {a) }}\end{array}$ & 30 & - & 3.32 & 3.14 & 94.5 \\
\hline $\begin{array}{l}\text { Ethyl phosphoro- } \\
\text { dichloridate }^{\text {a) }}\end{array}$ & 30 & - & 6.87 & 6.72 & 98.6 \\
\hline $\begin{array}{l}\text { Ethyl phosphoro- } \\
\text { dichloridothionate }^{\text {a) }}\end{array}$ & 30 & - & 6.59 & 6.53 & 99.1 \\
\hline $\begin{array}{l}\text { Dimethyl phosphoro- } \\
\text { chloridothionate }^{\text {a) }}\end{array}$ & 30 & - & 6.42 & 6.26 & 97.2 \\
\hline Triphenyl phosphine ${ }^{\text {a) }}$ & & - & 3.28 & 3.31 & 100.9 \\
\hline $\begin{array}{l}O \text {-ethyl } O, p \text {-nitro } \\
\text { phenylphosphonothiate }\end{array}$ & 90 & - & 0.0815 & $0.0796^{d)}$ & 97.7 \\
\hline$-\frac{-1 D P}{A D P}$ & $\begin{array}{r}30 \\
30\end{array}$ & $120^{\mathrm{e})}$ & $\begin{array}{l}1.29 \\
1.29\end{array}$ & $\begin{array}{l}-\overline{0.47} \\
1.29\end{array}$ & $\begin{array}{r}36.4 \\
100.0\end{array}$ \\
\hline ATP & $\begin{array}{l}30 \\
30\end{array}$ & $120^{\mathrm{e})}$ & $\begin{array}{l}1.09 \\
1.09\end{array}$ & $\begin{array}{l}0.18 \\
1.09\end{array}$ & $\begin{array}{r}16.5 \\
100.0\end{array}$ \\
\hline $\begin{array}{l}\text { Sodium diphosphate } \\
\text { decahydrate }\end{array}$ & $\begin{array}{l}30 \\
30\end{array}$ & $120^{\mathrm{e})}$ & $\begin{array}{l}1.20 \\
1.20\end{array}$ & $\begin{array}{l}0.06 \\
1.20\end{array}$ & $\begin{array}{r}4.5 \\
100.0\end{array}$ \\
\hline Sodium metaphosphate & $\begin{array}{l}30 \\
30 \\
\end{array}$ & $120^{\mathrm{e})}$ & $\begin{array}{l}1.34 \\
1.34\end{array}$ & $\begin{array}{l}0.06 \\
1.34 \\
\end{array}$ & $\begin{array}{r}5.0 \\
100.0 \\
\end{array}$ \\
\hline
\end{tabular}

*Resulting phosphate solutions were determined by IC.
a)Data were reproduced from reference 2 .
b) Heating temperature was $100^{\circ} \mathrm{C}$.
c) Hyphens indecate no heating, no acid added.
d) Concentrated 40-hold with pre-concentration column.
e) $0.5 \mathrm{~cm}^{3}$ of $1 \mathrm{~mol} \cdot \mathrm{dm}^{-3}$ oxalic acid solution was added. 


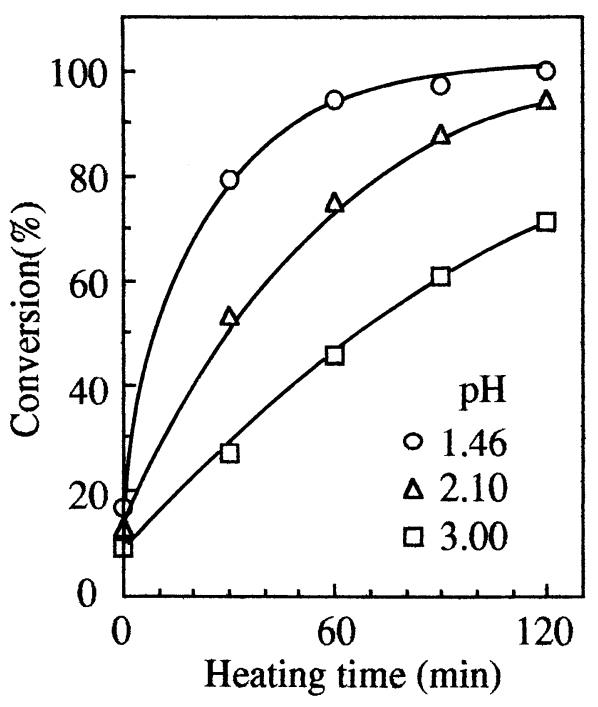

FIGUER 1 Decomposition of ATP reaction temp. : $100{ }^{\circ} \mathrm{C}$ uv iraadiation time : $30 \mathrm{~min}$ $\left[\mathrm{PO}_{4}{ }^{3-}\right]: 3.35 \mathrm{ppm}$

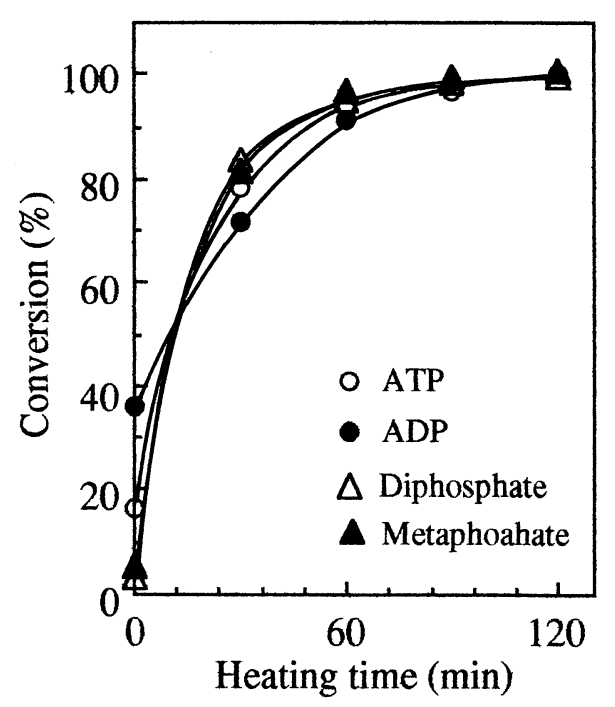

FIGUER 2 Decomposition of ATP, ADP, diphosphate and metaphoshate. reaction temp. : $100{ }^{\circ} \mathrm{C}$ reaction $\mathrm{pH}: 1.5$ uv irradiation time : $30 \mathrm{~min}$

\section{$\underline{\text { References }}$}

\section{JIS K0102-1993}

2 J. Itoh and M. Komata, Nippon Kagaku Kaishi, 10, 1768(1988)

3 J. T. H. Goossen and J. G. Kloosterboer, Anal. Chem., 50, 707(1978)

4 J. Beatie, C. Bricker and D. Garvin, Anal. Chem., 33, 1890(1961)

5 F. A. J. Armstrong, P. M. Williams and J. D. H. Strickland, Nature[London], 221, 481(1966)

6 A. Henriksen, Analyst[London], 95, 601(1970)

7 L. Zaiyou and Wu Limin, Talanta, 33, 98(1986)

8 J. Itoh and M. Komata, Analytical Sciences, 4, 117(1988) 